\title{
EMOTION MEETS TASTE: TASTE-MOTIVATED EMOTION TERMS IN ESTONIAN
}

\author{
Ene Vainik \\ Senior Research Fellow \\ Institute of the Estonian Language, Estonia \\ e-mail: ene.vainik@eki.ee
}

\begin{abstract}
The paper provides a systematic overview of the possibilities where the lexicons of emotion and taste meet in Estonian. Different levels of such "meeting points" are distinguished and the possible motivating factors discussed. The levels include both the figurative and literal usage of language, both the synchronic and diachronic perspective. The results demonstrate that there is figurative and systematic taste-to-emotion mapping both on the generic and specific level and in regard to both "good" and "bad" taste (and emotions, respectively). In addition, the literal terms of taste and emotions are used interchangeably on both sides of the evaluative distinction and have obsolete meanings as names of some specific substances as the prototypical carriers of the taste. The etymologies of the literal terms reveal an initial congenial conceptualisation of taste, emotion, and substance on both ends of the evaluative scale. In conclusion, today's systematic taste-to-emotion metaphoric mappings are found to be not only body-based and experientially grounded but to have deep historical and cultural roots.
\end{abstract}

Keywords: cultural linguistics, embodiment, emotion, Estonian language, metaphoric mapping, taste

\section{INTRODUCTION}

We all have experienced that food can taste either pleasant or disgusting. While making decisions and expressing our subjective preferences for food we often exploit some emotion terms (to please, disgust). Such evaluations seem very intuitive and natural. The object of the present paper is, however, not the emotional evaluation of taste but the other way around: the language of taste that is used to describe or characterise emotions. This "reverse" relation might seem less intuitive and natural in the beginning but the impression fades quickly if you think about expressions such as sweet love or bitter anger.

The situation of using some taste terms (e.g. the adjectives sweet and bitter) as the descriptors of emotions is not rare. In addition to the sweet love and bitter 
anger, one could find also other combinations such as sweet sadness (Apresjan 1997). Besides the descriptive pattern one can also notice the tendency to use sweet as a synonym of 'kind' and 'nice' in affective contexts (e.g.: How sweet of you to make that offer). The link between sweetness, subjective pleasantness, and affection is unconsciously further exploited in the very commonplace English endearments, such as Honey, Sugar or Candy.

The tendency to talk about some emotions in terms of taste has been noticed in many languages, among them both Indo-European and non-Indo-European. Quite lately, the topic has been brought up in respect of Seediq, an Austronesian language (Lee 2016). The data from Estonian (a Finno-Ugric language) also contribute to the overall picture of a possibly universal tendency.

The present paper was triggered by the observations of the author in the course of writing a monograph about the usage and semantics of Estonian emotion terms (Vainik 2016). Nineteen emotion terms (and respective concepts) were portrayed by integrating linguistic data from ten different levels of linguistic description and/or the type of source material (both standard Estonian and historical usage of the terms were tackled using dictionaries, corpora, databases of phraseology, dialects, runic songs, etc.). The author's attention was caught by the fact that emotions were described in terms of taste in quite a few occasions. It seems that the conceptualisations of emotions in terms of taste might have deeper historical roots in Estonian than in the Indo-European languages, where such expressions have been claimed to rely on purely metaphoric mapping (Sweetser 1990).

The aim of the present paper is to offer a systematic overview of the possibilities where the emotion and taste lexicons can meet, and of how these possibilities are used in Estonian. Such a structure can serve as a template for the further studies of other languages and/or cultural comparisons of different languages. In what follows, you will first find a brief section of the theoretical background, and then a structured layout of the different levels of conceptualisations. The findings will be summarised and discussed in every section and the final conclusions drawn at the end.

It must be mentioned that only qualitative distinctions are made and illustrated in the paper. The author has no ambition to rely on the usage of taste terms in the corpora or to detect experimentally what goes on in people's minds. What is explored here is the patterns of thought as crystallised in the linguistic expressions and, thus, revealing the underlying cognitive or other kind of motivation, if any. The examples illustrate the common sense knowledge of Estonian and have no references to the sources, unless they represent archaic usage or some specific context or meaning. In the latter case the references are given in the endnotes. 


\section{SOME NOTES ON THE BACKGROUND}

The question of a semantic motivation of emotion vocabulary has arisen in the paradigm of cognitively and culturally oriented linguistics (e.g. Kövecses 2000, $2005,2006,2008$ ). Within this line of research, it is accepted that although linguistic signs may be arbitrary symbols in principle, practically, there is often a semantic or other kind of motivation detectable between a linguistic form and its meaning. This holds particularly for the complex units, such as constructions that are compositional in nature, but not only (Langacker 1987). The topic of semantic motivation of metaphoric language makes full sense and is relevant in the cognitively and culturally oriented linguistics (see Kövecses 2015; Dobrovol'skij \& Piirainen 2005; Sharifian 2011; Vainik 2017).

While the motivation of emotion language is discussed, the notion of embodiment seems attractive. The embodiment hypothesis says that our bodily experience largely influences our understanding of the world and plays a crucial role in conceptualising other fields of experience (Sweetser 1990; Gibbs 2006). The abstract and experientially not so clearly delineated phenomena are claimed to be thought and talked about in terms of experience-related (and often bodily) terms (Lakoff \& Johnson 1980).

The mind-as-body metaphor proposed by E. Sweetser (1990) is a good example of this kind of theoretical approach. According to her suggestion, there is a tendency in the Indo-European languages (which might easily turn out to be a linguistic universal, in fact) that the body-related terminology is a source domain for conceptualising psychological states like emotions or for the language of logic, causation, and conversational structure. In regard to sense perception, she brings numerous examples of the etymologies originating in the physical realm. For example: the terms for vision might have referred originally to physical phenomena like the eyes, facial movements or light; the metaphors for vision originate in touching and manipulating as a more physical faculty. Vision, in turn, is more body-related than some other kinds of mental activities and can be used to refer metaphorically to knowledge and intellection (the UNDERSTANDING IS SEEING metaphor; see Lakoff \& Johnson 1999). It appears that there has existed a unidirectional flow of "borrowing" the terms for more abstract concepts from the more body-related faculties and not the other way around (Sweetser 1990: 35).

\subsection{Emotion-as-taste?}

It is not quite sure, however, whether the taste-to-emotion mappings would classify as a clear case of the mind-as-body metaphor. We can easily admit that 
emotions form part of our mental functioning and are, thus, a faculty of mind. Assigning taste to be a faculty of body is not as easily admittable. We are used to talk and think about taste as being one of the five classical senses and belonging, thus, to the faculty of sense perception, which is also part of our mind.

The tradition of distinguishing five senses (sight, hearing, touch, smell, and taste) has lasted for more than two thousand years, originating in the Aristotelian doctrine (see Sutrop 2002: 11). Whether the distinguished senses and the process of sense perception are to be labelled bodily or mental in nature is a matter of dispute. Perception is a highly complex kind of in-brain processing in itself. On the other hand, it includes "taking in" raw data: the environmental stimuli, which are further processed (identified, organised, and interpreted) in the brain. What makes the perception more "bodily" in our common sense knowledge (as compared to reasoning, memory or imagination, for example) is, perhaps, that the very initial part of it takes place in the specific body parts designed for that purpose (the eyes, ears, nose, tongue, and skin).

Ever since the Aristotelian times there has existed the hierarchy of senses. It means that sight and hearing, for example, were considered to be "higher" or more important than the senses of touch, smell or taste. The differently attributed importance is reflected in the development of lexical description. In a fully developed hierarchy the sequence of lexicalization goes as follows: sight $>$ hearing $>$ touch $>$ smell/taste (Viberg 1983). The implication of such a hierarchy is that if you lack a term for a modality, you can always "borrow" a term from the left (i.e. use a term of a higher order modality) and never from the right. Such a sequence predicts that the terms of taste can hardly be used for description of the other senses.

From the viewpoint of the present study, it means that if taste terms are used to describe emotions (and/or emotion related phenomena) it would automatically mean that emotions are treated as a different mental faculty where the "hierarchy of senses" does not apply. In the framework of cognitive linguistics this assumption is held, exactly: emotion and taste are treated as separate cognitive domains, one of those more concrete, familiar, and body-related (taste), and the other more abstract, less familiar, and not as easily tangible (emotion).

\subsection{Analogy in experience and beyond}

Sweetser (1990) explained the motivation of using sweet and bitter (the categories of taste) in order to describe emotions by the mechanism of analogy. She claimed that love pleases us in a way that is similar to the way sweet taste 
pleases our taste buds. In the same line of thought it is the unpleasantness of anger that makes its connection to the bitter taste.

One thing that might have been left unnoticed is the polarity of evaluations entailed by such a scenario: the emotion of love is opposed to the emotion of anger because of the oppositeness of their inherent evaluative values (pleasant vs unpleasant) and so is the sweet taste opposed to the bitter taste on the same kind of evaluative basis.

It seems that connecting sweetness to love and bitterness to anger is a quite abstract kind of decision and not truly related to any bodily sensation or imagination of respective tasting experience. The evaluative dichotomy pleasant vs unpleasant functions as a grounding in our knowledge, which reinforces if not causes us to see emotions and taste similar or analogous to each other.

The evaluative opposition goes far beyond the domains of taste and emotion - it is one of the so-called universal dimensions of the semantic space as established by Charles Osgood, George J. Suci, and Percy H. Tannenbaum (1975 [1957]). Their experiments proved that three dimensions - evaluation, activation, and potency - are the ultimate measures of human experience and occur pervasively in conceptualisation. Everything that can be thought about - and named - would be unconsciously measured on these dimensions.

Why to choose the taste of bitter rather than salty or sour to be the opposite of sweet in the domain of emotions seems to rely on the inherent negativity or displeasing quality of how the bitter taste was culturally conceptualised. In a traditional rural economy both salty and sour taste accompanied the processes of food conservation and made sense as the by-products of the survival techniques. The taste of bitter, however, had no such excuse and could be evaluated not only as displeasing but also as "useless" from the viewpoint of survival. On the contrary - the poisonous plants and substances were often recognised by their bitter taste.

\subsection{Conclusion of the background ideas}

As regards the present study, the starting point is an assumption that emotions and taste are different mental faculties which are represented in our knowledge as separate cognitive domains. The emotion conceptualisations are rooted in the bodily experience of taste due to inherent evaluations of pleasantness vs unpleasantness in both of the fields of experience.

In addition to the purely cognitive and embodied approach, we would consider also finding motivations for the taste-to-emotion mappings from cultural theories, religious ideas, and folk medicine. 


\section{CONCEPTUALISING EMOTIONS IN TERMS OF TASTE IN ESTONIAN}

A layout of the different levels of conceptualising some emotions and emotionrelated phenomena (such as general evaluations of like and dislike), using the domain of taste, is given in Table 1. The "meeting points" of taste and emotion occur both in the figurative and literal use of language, both in the present day and in the distant past as revealed by the etymologies. In the following section the "meeting points" are extended upon, illustrated with the Estonian examples, and the possible motivations of the conceptualisations are discussed.

Table 1. The "meeting points" of taste and emotion in Estonian.

\begin{tabular}{|c|c|c|c|}
\hline & \multicolumn{2}{|c|}{ Evaluation } \\
\hline & & "bad" & "good" \\
\hline \multirow{2}{*}{$\begin{array}{l}\text { Figurative speech } \\
\& \\
\text { metaphoric } \\
\text { mapping }\end{array}$} & Generic & $\begin{array}{l}\text { UNPLEASANTNESS IS BAD } \\
\text { TASTE }\end{array}$ & $\begin{array}{l}\text { PLEASANTNESS IS GOOD } \\
\text { TASTE } \\
\text { PLEASANTNESS IS AS } \\
\text { GOOD AS HONEY }\end{array}$ \\
\hline & Specific & $\begin{array}{l}\text { SUPPRESSED ANGER IS BITTER } \\
\text { TASTE } \\
\text { ANGER IS BILE }\end{array}$ & $\begin{array}{l}\text { THE FEELING OF } \\
\text { PLEASURE IS SWEET TASTE } \\
\text { LOVE IS HONEY }\end{array}$ \\
\hline \multirow{2}{*}{$\begin{array}{l}\text { Literal meaning } \\
\text { of the polysemous } \\
\text { terms }\end{array}$} & Noun & $\begin{array}{l}\text { viha1 'anger' } \\
\text { viha3 'bitterness; might' } \\
\text { viha4 'fester, pus' }\end{array}$ & magus2 'honey' \\
\hline & Adjective & viha2 'bitter' & $\begin{array}{l}\text { magus1 'sweet' } \\
\text { magus3 'delicious' } \\
\text { magus4 'pleasant' } \\
\text { magus5 'lovable' } \\
\text { magus6 'beloved' }\end{array}$ \\
\hline \multirow[b]{2}{*}{ Etymologies } & $\begin{array}{l}\text { Finno- } \\
\text { Ugric }\end{array}$ & & $\begin{array}{l}\text { meel < Finno- } \\
\text { Permic *mil 'mind' }\end{array}$ \\
\hline & $\begin{array}{l}\text { Indo- } \\
\text { European }\end{array}$ & $\begin{array}{l}\text { Proto-Indo-European } \\
\text { *viša 'poison' }\end{array}$ & $\begin{array}{l}\text { magus < Proto- } \\
\text { Germanic *smakjan } \\
\text { 'taste' } \\
\text { meel < ?Proto-Baltic } \\
\text { *mel 'uvula, tongue' }\end{array}$ \\
\hline
\end{tabular}




\subsection{Figurative speech and metaphoric mapping}

Figurative use of language can be defined as a situation where "what is said is not truly meant". The situation does not equal lying, however. There is no truth value to the figurative expressions, only the value of presenting some easily imaginable situation instead of something more subtle, complex or complicated. Such a substitute of the actual situation enables to highlight some of its characteristic aspects and to make stronger impact on the recipient.

In the framework of the Conceptual Metaphor Theory the more easily comprehendible domain is called the source domain and the more abstract phenomenon is called the target domain. The very mechanism of systematic mapping from the source to the target is called the conceptual metaphor (Lakoff \& Johnson 1980). In the present case, the mapping from the domain of taste to the domain of emotion classifies as a conceptual metaphor, if systematic.

\subsubsection{Conceptual mapping from taste to emotion on the generic level}

Conceptual taste-to-emotion mapping on the generic level means that the domain of taste is used to talk about person's general like and dislike but reference is made neither to any specific emotion nor to any specific quality of taste, except its subjective pleasantness vs unpleasantness. The quality of taste ("good" or "bad") is mapped onto the general and non-specific emotional evaluation of the situation (pleasant vs unpleasant). A conceptual metaphor responsible for such mappings can be expressed as follows: PLEASANTNESS IS GOOD TASTE / UNPLEASANTNESS IS BAD TASTE.

The well-known instances of this conceptual metaphor are expressions like not my cup of tea or not my piece of cake, in which personal dislike of something not belonging to the domain of food is expressed as excluding the thing from one's menu. Subjective dislike of bad taste as the reason for refusing an otherwise appealing object (a piece of cake, a cup of tea) is inferential in nature and not expressed explicitly. Therefore, expressions like this would fit well in the case when politeness is the strategy of conversation.

This may easily be the case also in Estonian, because there is the well-known proverb Maitse üle ei vaielda 'There is no accounting for taste (lit. One should not argue about taste)' meaning that one should not argue about one's subjective likes and dislikes. The existence of such a directive proverb reveals also a strive for "good behaviour", i.e. politeness. 


\subsubsection{Expressing subjective dislike by using some taste-related terms in Estonian}

Example 1 is the clearest instantiation of the conceptual metaphor UNPLEASANTNESS IS BAD TASTE. In example 2 taste as a source domain is combined with smell. The gesture of wrinkling one's nose refers to a situation of rejecting something as if tasting and smelling it concomitantly. Example 3 describes the situation of subjective dislike as a grimace, typical of a situation when one has taken a bit of something that he or she actually cannot ingest. In example 4 the reaction of rejecting something is hyperbolised into an even stronger image of vomiting. The latter is a typical expression of not only dislike but disgust, too.

(1) Pole päris minu maitse.

I do not like it, lit. not quite my taste.

(2) nina kirtsutama millegi peale

to dislike something, lit. to wrinkle one's nose at something

(3) haput nägu tegema

to spurn, lit. to make a sour face

(4) Poliitikute jutt ajab mind oksele.

The politicians' talk is disgusting, lit. makes me vomit.

The examples of figurative speech give us an image of a complex situation of being about to ingest a portion of rotten food: bad taste combines with disgusting smell and potential damage because of the bad quality of the food. What a clear image for expressing subjective dislike!

\subsubsection{Expressing subjective liking by using taste-related terms}

\section{in Estonian}

The conceptual metaphor PLEASANTNESS IS GOOD TASTE is instantiated in quite a few expressions, among them the ones similar to examples 5 and 6 . The situation of intense liking is hyperbolized into an image of strongly wanting something by describing the situation as the state of physiological desire for food with all the concomitant sensations (examples 7 and 8).

(5) See on just minu maitse!

I like it! lit. It fits my taste.

(6) mokka mööda olema

to like something, lit. fit one's lips 
neelud käivad millegi järele

to want something, lit. to dry-swallow (for something)

Tal ila jookseb.

He strongly desires something, lit. he has slobber dripping.

To describe very pleasant things, an Estonian would use a simile magus nagu mesi 'sweet as honey'. For the situation of hearing good, pleasant news there is an expression (example 9) in which the image of ingesting a mouthful of honey is blended with the image of pleasant audition. Most probably, the understanding of pleasantness in terms of good taste is blended with the fixed expression nagu muusika minu kõrvadele 'like music to my ears':

See on mesi minu kõrvadele.

I like to hear it very much, lit. it is honey to my ears.

In the expression above, the generic metaphor PLEASANTNESS IS GOOD TASTE is slightly modified to be more specific: PLEASANTNESS IS TASTE AS GOOD AS HONEY.

The evaluation of subjective pleasantness is relevant also in human relations. In fact, the positive evaluation towards us is something that we all aspire for. Flattering behaviour, however, is figuratively downplayed by hyperbolic descriptions in which the flattering person is described as if offering tasty food (example 10) or even being such a food (example 11).

mett moka peale määrima

to flatter by making compliments, lit. spread honey on someone's lips

(11) Ta oli minuga nagu sulavõi.

He tried to please me, lit. he was like liquid (melted) butter with me.

Behind the expressions in the examples 10 and 11 there is the image of bargaining and the folk psychological understanding that sympathy or privileges can be granted in exchange for tasty food. Estonian has coined also a special verb for the verbal flattering behaviour - moosima 'to flatter, lit. to be jam-like'.

\subsubsection{Conclusion and discussion}

To conclude the section of the generic level mappings from taste to emotion, one must admit that the mappings are systematic in Estonian, and can, thus, be considered to qualify as the conceptual metaphor PLEASANTNESS IS GOOD TASTE / UNPLEASANTNESS IS BAD TASTE. 
The two submetaphors of the general pattern comprise an antonymic pair of the kind, which is similar to the orientation metaphors (e.g. GOOD IS UP / BAD IS DOwN) (Lakoff \& Johnson 1980), except that the opposite evaluations are connected to one's subjective taste (good taste vs bad taste) instead of observable (and, thus, more objective) orientation in space.

Using the labels "good taste" and "bad taste" for the judgements of subjective pleasantness vs unpleasantness of something more abstract is a tradition that originates in the British eighteenth century sentimentalist tradition of philosophy. The "judgment of taste" as the essence of the aesthetic judgement was also central to Kant's account ${ }^{1}$. It is also said that the concept of the aesthetics in itself descends from the concept of taste ${ }^{2}$. The etymology of the term aesthetics (Greek aisthetikos 'sensitive, perceptive' ${ }^{3}$ ), however, refers to perception in general and not only the modality of taste. It is said that this is because of all the five senses 'taste' is the one most closely associated with fine discrimination, hence the familiar secondary uses of words for 'taste, good taste' with reference to aesthetic appreciation. ${ }^{4}$

Having tackled the Estonian examples, one would hardly say that the tasterelated evaluations belong to the politeness register or have to do with aesthetic judgement, except maybe the expression in example 5. Instead, one can find strong descriptive images full of physical details. The aesthetic categories first developed in the eighteenth century Europe have made their way into the Estonian folk psychology, apparently, because of being reinforced by the close-to-the-body (and close to the everyday experience) conceptual grounding.

\subsubsection{Conceptual mapping from taste to emotion on the specific level}

Conceptual mapping on the specific level means that a specific emotion (with its own literal label, such as love) is conceptualised in terms of some specific taste which also has its own literal label, such as sweet, for example. As a result, love is conceptualised as sweet taste (not just as good taste). In regard to the specific taste-to-emotion mappings there occur two conceptual metaphors that are similar to those in English: ANGER IS BITTER TASTE and LOVE IS SWEET TASTE.

\subsubsection{A specific bad emotion is described in terms of a specific}

\section{bad taste}

The genuine taste term that is mostly used in the specific level mapping to describe a negative emotion is the simple adjective kibe 'bitter'. In most expressions, however, there occur derived words (the noun kibedus 'bitterness' 
and adverbs kibedalt, kibedasti 'bitterly'). A synonymous adjectival root mõru 'bitter' is also sometimes used.

The emotion metaphorically referred to by the Estonian noun kibedus 'lit. bitterness' is not the overt expression of anger but a kind of non-expressed and suppressed feeling, which is often related to giving up one's own will and aspirations. The feelings of disappointment and being hurt are also similar to kibedus 'bitterness'. Paradoxically, it is difficult to define or to describe the feeling in literal terms while the figurative term kibedus 'bitterness' seems to be kind of self-explanatory in respect of how the feeling affects the sensing self. The feeling kibedus 'bitterness' is as painful to the soul as the taste of bitter is to one's taste buds: one would survive the experience but definitely not enjoy the sensation.

It is not rare to find the feeling of kibedus 'bitterness' to be mentioned as accompanying one's thoughts (example 12) or verbal expression (examples 13-15).

(12) Ta mõtles kibedusega oma lastele, kes temast ei hoolinud. She thought with bitterness about her children who did not care about her.

(13) Ta rääkis juhtunust äärmise kibedusega.

She talked with an extreme bitterness about what had happened.

(14) Ta ütles seda mõrult.

He said it bitterly.

Tema hääles kõlas kibedus.

Bitterness sounded in his voice.

Bitterness as the non-expressed anger can be described as causing inner tension in the self, very much in the way similar to the case of the conceptual metaphor ANGER IS HOT/PRESSURIZED LIQUID IN A CONTAINER (Kövecses 2000). The human "container" can be instantiated either by süda 'heart', hing 'soul' or meel 'mind' (example 16, 19). Expressions such as in example 17 reveal the liquid-like nature of emotion. The description of the pressurising effect can be attained also by making reference to fermentation typical for brewing alcohol (example 18), and by describing someone as erupting (example 19).

Ta hinge täitis kibedus.

His soul was filled with bitterness.

Ta valas kogu oma kibeduse välja.

He expressed his bitterness, lit. poured all his bitterness out. 
Kibe viha kääris temas.

He was getting more and more angry, lit. bitter anger bubbled in him.

Ta südamesse kogunenud kibedus purskus välja.

The bitterness stored in his heart spouted out.

According to folk psychology, on the other hand, the supressed anger that remains unexpressed (called metaphorically kibedus 'bitterness') would turn into a personality trait. The Estonian language has coined a special verb to describe such a process: kibestuma ('to sour, embitter, lit. to become bitter').

The specific-level mappings from taste to emotions can be even more specific: there are expressions that reveal what kind of substance is meant as the typical carrier of bitterness. Examples 20-23 demonstrate that the substance in question is bile. One can recognise the same typical contexts as in the case of bitterness: verbal expression (20), containment of the substance in one's soul (21) and pouring the liquid out while expressing the long-suppressed emotion. The latter aspect is described hyperbolically in example 23, as if bile has been kept under pressure in one's soul.

(20) sapine märkus

a mean remark, lit. bilious remark

(21) hinge sappi koguma

to accumulate anger, lit. to gather bile in one's soul

(22) Ta valas oma sapi lõpuks välja.

He expressed his angry feelings eventually, lit. poured his bile out.

\section{sappi pritsima}

to talk angrily, lit. to sprinkle bile

The examples above show that the conceptual metaphor ANGER IS BITTER TASTE has a more specific variation in Estonian, namely SUPRESSED ANGER IS BITTER TASTE. It seems to have entailments such as: being related to one's thoughts, hiddenness and containment in the human locus of emotion (the heart, soul or mind), accumulation and hence the effects of pressure, and the liquid-like nature while expressing it. In quite a few expressions an overt reference was made to bile as the most prototypical bitter substance familiar from one's bodily experience. 


\subsubsection{A specific good emotion is described in terms of specific good taste}

The specific good taste that figuratively represents the pleasantness of positive emotions is instantiated by the adjective magus 'sweet' in Estonian. In fact, it is not only love that can be described by that term but a whole family of positive emotions. One can easily say magus armastus 'sweet love' as well as magus õnnetunne 'sweet feeling of happiness' magus rõóm 'sweet joy', magus rahulolu 'sweet content'. Besides positive emotions also somewhat ambivalent states such as igatsus 'longing', ootus 'anticipation' and even valu 'pain' can be described as magus 'sweet' (EED 2009).

The specific taste term magus 'sweet' accompanies a somewhat open set of emotion names. This is so because the adjective magus is used as the modifier of an emotion term and is, thus, figuratively characterising the sensation accompanying the feeling rather than directly and solely referring to that particular feeling. The common denominator of the emotional states seems to be the feeling of pleasure that the emotional states evoke in the experiencing self. Therefore, the conceptual metaphor in Estonian would be: PLEASURE IS SWEET TASTE. The term for pleasure - mõnu - also belongs to the set of specific level emotion terms in Estonian (Vainik 2004, 2016).

The derived noun magusus 'sweetness' is not used to name an emotion in the same way as the derived term kibedus 'bitterness' is. However, magusus as a noun can refer to verbal expression of love and meretricious friendliness (24) or be a characteristic of one's voice (25) while expressing those feelings.

Teda häiris värsside nõretav magusus. (EED 2009)

He was bothered by the cloying verses, lit. he was bothered by the dripping sweetness of the verses.

Ta hääles on lipitsevat magusust. (EED 2009)

There is flattering sweetness in his voice.

Oh armastus, sina kallis magus mesi! ${ }^{5}$

Oh love, you dear sweet honey!

Oh, mis magus on peigmees olla! (Jannsen 1854)

Oh, how sweet it is to be a groom!

However, one can find also examples (like in 26) where magus 'sweet' is attributed directly to love. The image is more specific, while a reference is made to the most typical sweet substance that one is familiar with - mesi 'honey'. The particular phrase in example 26 originates in a title of a show where 
the Estonian folk songs and folk-like songs from the nineteenth century were performed. This kind of expressions were characteristic of the genre of sentimentalist poetry (see also example 27, a typical sentimentalist phrase from the nineteenth century literature).

However, one can find a description of arm 'love' as magus 'sweet' also in the Estonian runic songs that are much more archaic (Kama 2017 and his references). Example 28 presents a raw naturalistic image of the erotic kind of love. The emotion is referred to by the plural form magusad armud 'sweet loves'.

\author{
Pidin Pillele minema \\ jäin aga Mallele magama \\ Malle armud magusamad \\ kui need Pille piima toobid. ${ }^{6}$ \\ I was about to marry Pille \\ But I found myself sleeping on Malle \\ [Because] Malle's loves are sweeter \\ Than Pille's buckets of milk [the breasts].
}

The term magus 'sweet', while used about feelings, catches not only the immediate pleasurableness of the state but contains also the semantic component of its desirability. Examples 29-30 originate in Old Literary Estonian (Lauluraamat 1727 [1721]). The meaning of the word arm 'love' cannot be identified with eros here but with the religious concept known as agape (Soosaar 2016).

(29) Oo sina magus arm, anna minul sinu armu.

Oh, thou sweet love, give me your love.

(30) Sa magus arm [...] et armastame teine teist nü̈̈d südamest [...] Thou, sweet love [...] let us love each other from the heart [...]

In conclusion, the conceptual metaphor PLEASURE IS SWEET TASTE has entailments such as being related to verbal expression and being experienced by both one's mind and body. Besides the actual enjoyment of the state also the desirability of such an experience belongs to the semantic complex of pleasure-as-sweetness. Conceptualising the feeling of love (both agape and eros) in terms of sweetness appears to be a special instantiation of the metaphor. Love is considered to be the ultimate pleasing experience to one's soul and body, and, thus, the sweetest. Honey as the specific substance instantiates the ultimate sweetness/pleasantness one can think of. 


\subsubsection{Conclusion and discussion}

To conclude the section of the specific level mappings from taste to emotion, one must admit that the mappings in Estonian are systematic and therefore there exist two conceptual metaphors: SUPRESSED (NON-EXPRESSED) ANGER IS BITTER TASTE and PLEASURE IS SWEET TASTE. Whether these two taken together comprise a pair of antonyms similar to the orientation metaphors (GOOD IS UP / BAD IS Down; Lakoff \& Johnson 1980) is problematic.

On the one hand, the oppositeness of love and being bitter as feelings as well as behavioural strategies has been cultivated by the Christian religion. Example 31 is an excerpt from the eighteenth century bible translation, where 'love' and 'being bitter' are considered as conceptual opposites, no matter that one of the antonyms refers literally to taste and the other to an emotion. The evaluative value is more important than being precise referentially.

\section{Teie mehed armastage omad naised ning olge mitte kibedad nende vastu.}

You, men, love your wives and be not bitter towards them.

On the other hand, it is possible that these two specific level metaphors are not similar to the orientation metaphors but are structural in nature and comparable, thus, to the metaphors like TIME IS MONEY and LOVE IS A JOURNEY (Lakoff \& Johnson 1980). These kinds of metaphors come each with its own motivation. They do not have to comprise a higher order system with the opposing extremes. In the following section some aspects of the possible motivations behind the specific level taste-to-emotion mappings will be discussed.

The examples given above (20-23) showed that besides being more specific in kind (suppressed anger instead of just anger), some expressions did actually make reference to the specific substance - bile, which might have functioned as a prototype. Everyone taking part in rural economy was supposed to know and recognise the bitter and unpleasant taste of bile.

On the other hand, it is also very likely that both bitter taste and the references to bile in the descriptions of hidden anger have to do with a cultural theory, namely, with the theory of the four bodily fluids (see, e.g., Geeraerts \& Grondelaers 1995; Geeraerts 2009). This theory, originating in antiquity, was revived in the Middle Ages as an explanation for the illnesses and for the individual differences in peoples' temperament. According to the theory, the excess of yellow bile in a person's body was the reason for proneness to anger and violent behaviour (hence the term choleric < khole Gr. 'yellow bile'). This theory, still popular in the period of Enlightenment, influenced and shaped, apparently, the folk understanding of the physiological effects of anger. Interestingly, there 
is a written record in Estonian from the eighteenth century, an Estonian version of Peter Ernst Wilde's book, by a Baltic Germanic scholar August Wilhelm Hupel:

See ema kes ennast vihastab, ei pea mitte kesk oma viha sees last imetama, sest kui laps seda piima mis viha läbi on palavaks ning sappi täis saanud, enese sisse imeb, siis ta jääb haigeks, tunneb valu, saab vigaseks, ehk sureb koguni armuta [...] Parem on et laps näljab ning nutab, kui et tema piimaga surmarohto ja kiwti ennese sisse nelab. (Wilde 1771)

The mother who gets angry should not breastfeed her baby while being in the midst of her anger because when the baby sucks up the milk that has become hot and full of bile due to the anger, the baby will get sick, feel pain, become handicapped or even die in a merciless manner. [...] It is better for the baby to starve and cry than to ingest the deadly drug and poison with the milk.

Thus it was believed and taught that psycho(physio)logical conditions like being angry can cause changes in the consistence and quality of mother's milk, which, in turn, could have an effect on the wellbeing of the baby. In regard to the emotion of anger, there seemed to be a firm relation between 'angry behaviour', 'hotness', and 'bile', which is exactly what was taught by the theory of the four bodily fluids (see, e.g., Geeraerts \& Grondelaers 1995; Geeraerts 2009). The same excerpt reveals also that the Estonian viha 'anger' was identified with 'poison'.

The other of the two taste-to-emotion metaphors - PLEASURE IS SWEET TASTE is a bit less specific than its English counterpart LOVE IS SWEET TASTE. The feeling of love occurs as an instantiation of the sweet pleasure that one can enjoy and strive for. Again, there is a specific substance - honey - that serves as the prototypical carrier of the sweet taste.

There seems to be no such well-formed cultural theory available explaining the sweetness of pleasure as there is for the bitterness or anger. The motivation for thinking about pleasure in terms of sweet taste seems to have purely experiential basis. Actually, sweet taste can be attributed to a wider range of emotions and states than just pleasure or love (sweet sadness and sweet pain included). Sweetness as the characteristic of one's emotional state was in fashion in the sentimentalist literature and is somewhat less fashionable in today's business-like and rationalist usage of language.

In conclusion, the two specific taste-to-emotion mappings have each their own motivation and specific substances as the prototypical carriers of the bitter and sweet taste respectively. There is no need to consider the conceptual metaphors as a fixed pair of antonyms, nor do they inevitably belong to a broader folk psychological theory of "emotions-as-tastes". There is, however, still a kind 
of similarity or symmetry between them. Namely, both tastes can be attributed to and recognised from the quality of one's voice and verbal expression (cf. examples 13-15 and 24-25). This observation brings us to notice degustation and speaking as the two main functions of the tongue as the purely physical organ.

\subsection{Literal co-conceptualisation}

The general assumption about the literal meaning of a word or literal usage of language is that "what is said is truly meant". Words are used in the most direct way referring to their denotations only. There should be no place for terms of emotion and terms of taste to meet, nor to get mixed in the case such a bijection of form and meaning would really exist. There are, however, the possibilities that are created by polysemy: a word that classifies as a genuine taste term by its first and main meaning can have an emotion reading its secondary or tertiary sense, and the other way around: a term originally coined for an emotion could have acquired a reading as a taste term. In the following section the "meeting points" that are caused by polysemy of the taste and emotion terms in Estonian will be presented and discussed.

\subsubsection{The same term for bad taste and bad emotion}

Interestingly enough, the root viha occurs as a noun and as an adjective in Estonian. In the descriptive dictionary (EED 2009) there are four senses listed: it has the meaning 'bitter' (as an adjective, viha2), and the senses of the noun diverge in three directions: viha1 'anger, hatred', viha3 'bitterness; might', viha4 'fester, rot'. All the senses except viha1 'anger, hatred' are somewhat obsolete. The last sense 'fester, rot' has gone extinct as an independent word; the meaning can be detected only in some obsolete compounds designating the effects of unsanitary conditions like küüneviha (lit. fester of the nails) and maaviha (lit. fester of the soil). As such, the obsolete viha 'fester, rot' used to belong to the Estonian folk medicine and reflects the (mis)understandings of the Estonian peasants about the causes of diseases. The noun viha3 'bitterness, might' is also obsolete; the examples in the dictionary (EED 2009) come from the contexts of traditional alcohol brewing and from the descriptions of degustating alcohol and tobacco, only. In some way or another the obsolete meanings of the root viha ('bitter', 'bitterness, might' and 'fester, rot') seem to form an interconnected bunch of senses reflecting the archaic understanding that held in the traditional rural society. It is remarkable that the term for an emotion 'anger, hatred' is literally the same. 
One can argue that viha 'anger, hatred' is the same as viha 'bitter taste' because anger is a 'bitter feeling': it affects our soul in the way that is analogous to the way bitter taste affects our taste buds. The rationale for the meaning extension from 'bitter taste' to 'bitter feeling' and then further to 'anger' can be seen as parallel to deriving the term kibedus 'bitterness' for the supressed anger (see section 3.1.2.1 above). This scenario seems to hold an assumption that the adjective viha 'bitter' was the first and oldest of the senses. This might, however, not be the case: the adjectival meaning of the 'bitter' (taste) can be an extension in itself, originating in the taste of a certain substance of which bitterness was characteristic. The contexts reveal that alcohol and tobacco would be the candidates for such a substance. Based on the discussion in section 3.1.2.1, we can also assume that the substance was bile.

The sequence of meaning development of the word viha would be as follows: 'a specific bitter substance' > 'bitter' (adj.) > 'bitterness' > 'anger'. This scenario, however, does not answer the question about what it all has to do with folk medicine and the 'magic cause of diseases' as one of the obsolete meanings of the term viha. Therefore, in a section below (3.3.1) I will tackle also the etymology of the term.

\subsubsection{Same term for good taste and good emotion}

The literal taste term magus 'sweet' is also a polysemous word - seven senses are listed in the dictionary (EED 2009). It occurs mostly as an adjective: magus 1 'sweet' (taste, smell), magus3 'delicious, appealing', magus4 'pleasant, enjoyable', magus5 'lovable, kind' (about people, words), magus6 'dear, beloved', magus 7 'convenient' (about time). One can follow the gradual change of meaning from taste to general pleasantness and then even further to the domain of interpersonal relationships ('lovable' and 'beloved').

One of its readings (magus2) is a noun with the meaning 'honey'. This sense is marked as obsolete in the dictionary (EED 2009). It is not clear whether the substance - honey - has been named magus after its characteristic taste or the other way around, so that the adjectival senses are extensions of the original name of the sweetest substance.

\subsubsection{Conclusion and discussion}

On both the positive (pleasant) and negative (unpleasant) side of the evaluative scale we can notice that the taste terms and emotion terms occur somehow interchangeably. The emotion term viha 'anger' has obsolete meanings revealing its 
connection to taste experience, and the taste term magus has developed meanings that extend to 'general pleasantness' and further to 'beloved' and 'lovable'.

One of the reasons of such confusion in regard to the reference may lay in the values cultivated by the Christian religion. Namely, it was strongly held that sweet and bitter taste are the opposites that must be kept apart in the same way as good and evil (see example 32 of Old Literary Estonian):

\begin{abstract}
Hädda neile, kes kurja heaks, ja head kurjaks hü̈̈dwad; kes pannewad pimmedust walgusseks, ja walgust pimmedusseks; kes pannewad wihha maggusaks, ja maggusat wihhaks. (Js5:20) Cursed are those who give the name of good to evil, and of evil to what is good: who make light dark, and dark light: who make bitter sweet, and sweet bitter! ${ }^{7}$
\end{abstract}

Apparently, the words for the phenomena on the good side (good taste, good behaviour, good emotions) can be used interchangeably and so can the words for the phenomena on the bad side (bad taste, bad behaviour, bad emotions), as long as the main distinction of good and evil is made. For example, sweet taste could be attributed to light (a phenomenon of vision, not tasting) because it was considered useful, and, thus, pleasurable and good (example 33).

Ja walgus on maggus, ja silmile on hea päikest nähha.

(PblR Kg11:7)

Truly the light is sweet, and it is good for the eyes to see the sun. ${ }^{8}$

Again, we can conclude that the evaluative value is more important as a characteristic than as being precise referentially.

\title{
3.3 The etymologies of the terms
}

The sections above have shown that there is a figurative and systematic tasteto-emotion mapping in regard to both the good and bad taste (and emotions, respectively). Moreover, we have seen that in Estonian the literal terms for taste and emotions are used somehow interchangeably on both sides of the evaluative distinction. In addition to this, I have noticed references to some specific substances as typical carriers of the tastes, and that the substances appear also in the lists of senses of the polysemous terms in the dictionary (EED 2009). It is not always clear, however, in which direction the meaning has developed: did it all start from a specific taste or from a specific substance. The emotional meaning seems to be secondary and appear later, however. Therefore, it seems to make sense to look at the etymologies of the terms, hoping that the distant past will reveal where the taste-to-emotion mapping originated and which (if any) substance was involved in the original conceptualisations. 


\subsubsection{Etymology of the root viha}

It appears that the root in which the Estonian term for bitter taste and emotion of anger originates dates back to the Stone Age (ca 2000-3000 BC; see Vainik 2014). The root viha has cognates in all of the Finnic languages (meaning 'anger', 'hatred', 'meanness', 'irritation', 'festering', 'bitter', 'tar of a pipe', 'poison'), and in the Finno-Ugric branch (Udmurt vož 'green', Komi vež 'green, raw, bright'). It has been concluded that the word originates in the Proto-Indo-Iranian root *viša- 'poison' (EDE 2012).

Such an etymology clearly puts the sense as a certain substance - poison to the very origin of the conceptualisation. It seems that the root viha (viša) congenially included the knowledge of certain qualities like having a bad, even fatal influence on one's health ('poison' $\rightarrow$ 'irritation, festering'), being subjectively unpleasant ('poison' $\rightarrow$ 'bitter'), making evil to one's enemies ('poison' $\rightarrow$ 'meanness, hatred, anger'). The Finno-Ugric cognates reveal that the greenishyellowish colour has also been part of that congenial conceptualisation.

Interestingly, bad influence and meanness to others (the emotional meaning) seem to have been co-conceptualised from the very beginning. The suspected taste-to-emotion mapping would rather be a part of general extension of the meaning 'poison' to many fields. Possibly, the meaning shift from poison to emotion happened as long as 5000 years ago. The etymologists assume that the Estonian verb vihkama 'to hate' also originates in Proto-Indo-Iranian root *dviš- 'to hate' (EDE 2012).

What can be the archetype of such a poison? One candidate proposed in the literature (Masing 2004) and discussed above (section 3.1.2.1) is bile - its colour and taste would fit well, at least. One has to consider, however, that the congenial conceptualisation of viha (viša) took place long before the theory of the four bodily fluids was formed by Hippocrates (about 400 BC). Another candidate for such a greenish, poisonous, bitter and dangerous substance would be the sap of some plants - aconitum ferox, for example, which was known by the name visha in the Ayurvedic medicine (Khare 2004). But, again, it may be the other way around: the plant was named visha because it was discovered to be deadly poisonous.

\subsubsection{The etymologies of the terms for good taste and good emotion}

The Estonian word magus 'sweet', which has also other meanings, such as 'honey', 'delicious', 'pleasant', 'lovable', and 'beloved', is a derived word that 
contains an adjectival suffix $-s$ and the root magu with an obsolete meaning 'taste'. The original meaning of magus seems to have been 'tasty'. The root magu has its origins in Proto-Germanic *smaka-z, *smakka-z 'taste' (EDE 2012) and dates, thus, to the Pre-Roman Iron Age (Vainik 2014). The homonymous word magu 'tummy' is claimed to originate in another Proto-Germanic root *magan- 'tummy'. The semantic relation between 'taste' and 'tummy' is not difficult to recognise.

The current etymology suggests that the original meaning of the root magu was neutral 'taste' rather than the specific and overtly pleasant sense 'sweet'. Apparently, there was still a default positive value to the meaning - the food, which was categorised 'tasty' by degustation (tasting) was appropriate for eating and, thus, pleasant.

There is another root in the field of emotions with a relevant etymology. This is the root that occurs in the verb meeldima 'to like'. Both of the Estonian terms for general subjective evaluation - the positive meeldiv 'pleasant' and negative ebameeldiv 'unpleasant' - are derivations from that verb. The latter is a complex form that contains denial (eba 'non' + meeldiv 'pleasant').

The verb meeldima 'to like' was invented by Johannes Aavik (1921) as a neologism. The word is derived from an Estonian root meel, which has many related meanings, among them 'sense', 'mind', and 'mood' (EED 2009). The derived term meeldima was intended as a replacement for the multiword expression meele järele olema 'to like, lit. to be after one's sense $/ \mathrm{mind} / \mathrm{mood}$ '. The old conceptualisation constructed the situation of subjective liking as a spatial image of following one's "organ of decision" - meel 'sense/mind/mood'. The spatial construal reveals the initial default positive value attributed to the concept meel 'sense/mind/mood'. In the Estonian runic songs there existed an adjective derived directly from the same root - meeleline 'pleasant, sweet' (Vainik 2016). The original emotional appeal caught into the root meel is still preserved in the derived verb meelitama 'to blandish'.

The official etymology of the word meel claims it to be of Finno-Permic origin with the very similar meaning as today - 'sense/mind/mood' (EDE 2012). Such an abstract conceptualisation of a complex "organ" of perception, cognition, and emotion is rather surprising, considering the lifestyle and physical conditions of the hunter-gatherers during the Bronze Age (approximately $1000 \mathrm{BC}$; see Vainik 2014). Therefore, one could consider also the possibility to date the root further back to the Proto-Baltic *mel- 'uvula, tongue'. ${ }^{9}$ A word referring to a bodily organ of swallowing and tasting seems a more likely origin for a word that later developed into a concept that catches the complex "organ" of perception, cognition, and emotion, and further, being the derivational root for conceptualising subjective liking. 
The default positive value attributed to the organ of swallowing might have to do with its even more ancient origin in the Proto-Indo-European root, the cognates of which were Old Greek méli 'honey' and Latin mel 'honey'. Honey would fit well as an archetype of the sweetest substance known throughout the whole history. Such a speculation would drive us, again, to assume some kind of initial congenial conception of 'fitting one's tongue', 'good (sweet) taste' and 'appeal' as positive emotional evaluation.

\subsubsection{Conclusion and discussion}

The perspective taken by tackling the etymologies of the two Estonian taste terms reveals that their roots date back to the prehistoric times: magus to the Pre-Roman Iron Age and viha to the Stone Age. The roots (and respective conceptualisations) go, thus, far beyond the Estonian language.

In respect of viha there appears to have taken place a congenial conceptualisation of 'poison' in the Proto-Indo-Iranian and, possibly, concomitantly, in the Finno-Ugric languages that were in contact at these times. The co-conceptualisation includes the poison's bitter taste, its fatal effects on one's health, the aversive emotional attitude, and its greenish colour. The features were attributed to the substance that was believed to be the carrier of those effects. It is not clear, however, whether the archetype of such a substance was bile or sap of some poisonous plant.

As regards the origins of magus, it is not comparable to viha in respect of such a congenial conceptualisation. The word originally meant 'tasty'; its extensions to the more specific senses such as 'sweet' and to the emotional meanings (like 'pleasant', 'lovable', and 'beloved') have taken place later. However, there seems to have been a seed of positivity present in the very beginning of the conceptualisation - the approval of the edible things by one's taste organs and digestion.

In addition to these two roots of the specific taste/emotion distinctions, also the etymology of the root meel 'sense/mind/mood' was considered relevant as a derivational source of both the terms of like (meeldiv) and dislike (ebameel$d i v)$. It was found that, originating as deep in history as the Bronze Age, it might have had a more concrete and body-related origin in the Proto-Baltic root *mel- 'tongue, uvula'. Such an embodied original meaning fits better into the understanding that abstract concepts are bodily rooted (Sweetser 1990). An organ of taste/swallowing is a good analogy for conceptualising meel as an organ of fast decision making. 


\section{A SHORT SUMMARY OF THE STUDY}

Table 1 outlined the areas of the Estonian language where the words of taste and emotion meet. In the subsequent sections the "meeting points" were expanded upon and illustrated with some examples. The conclusions were also drawn and the possible motivations discussed. There seems to be no need for an extensive overall conclusion or discussion. In the following only the highlights of the study are briefly reported.

To put the main result very simply: the taste-emotion connection is more deeply rooted than the cognitive linguists have thought. Today's systematic taste-to-emotion metaphoric mappings are not only body-based and experientially grounded but have deep historical and cultural roots.

Part of the history is the conscious and deliberate turn to "senses", which occurred in the philosophical thought in the seventeenth-eighteenth centuries. Taste was considered to be the most delicate of the five senses and therefore fit for aesthetic judgement. The Estonian material shows that the taste-related imagery has lost its initial delicacy and relation to aesthetics, and given rise to an array of lush body-based extensions. The antonymic pair of conceptual orientation metaphors PLEASANTNESS IS GOOD TASTE / UNPLEASANTNESS IS BAD TASTE is a practical tool in everyday situations, which comprises the essence of the so-called "gut feeling".

Another historical root that was identified was the influence of the theory of the four bodily fluids. The specific level metaphoric mapping SUPRESSED (NON-EXPRESSED) ANGER IS BITTER TASTE could be attributed to the understanding cultivated by the theory that anger was caused by the excess of yellow bile in one's body. The misunderstanding has made its way to influence the Estonian folk psychology. The other specific level conceptual metaphor PLEASURE IS SWEET TASTE seems to lay on a more experiential bodily basis. The "sweet feelings" were boosted in the eighteenth-nineteenth centuries via sentimental literature.

Yet another historical root of the practice to talk about emotions in terms of taste lies in the fact that the Estonian terms of taste and emotions have etymologies that reveal their initial congenial conceptualisation. Today's polysemy contains many obsolete meanings that reveal a practice to use the same words interchangeably, referring to taste, emotions, and to the most prototypical substance carrying the taste.

Apparently for ages, until the psychological awakening in the nineteenth century and the rise of general knowledge that resulted in the birth of disciplines such as psychology, it was more important to keep apart the evaluative extremes of good and evil than to make clear distinctions between the psychological faculties (e.g. sensing the taste vs emotions). A major stress on distinguishing 
between the polar opposites of "good" and "bad" can be attributed to the influence of the Christian religion - another historical cultural factor behind the emotion conceptualisations.

One must admit, however, that telling apart what is "good" and "bad" in terms of what is edible and what is not is an inescapable need that saves lives. Without these categories we, humans, could not have expanded in such numbers. In order to avoid mistakes costly for the survival, the categories of good and bad taste and emotional attitudes such as appeal and need for aversion must be communicated verbally. Human tongue might be the place where taste and emotion literally meet each other.

\section{NOTES}

1 See http://plato.stanford.edu/entries/aesthetic-judgment/, last accessed on 8 February 2018.

2 See http://plato.stanford.edu/entries/aesthetic-concept/\#ConTas, last accessed on 8 February 2018.

3 See http://www.etymonline.com/index.php?allowed_in_frame=0\&search=aesthetic, last accessed on 8 February 2018.

4 See http://www.etymonline.com/index.php?allowed_in_frame=0\&search=taste, last accessed on 8 February 2018, and Buck 1949.

5 See http://erb.nlib.ee/?kid=21836206, last accessed on 7 February 2018.

6 EÜS IX 1137/8 (93) < Rakvere Parish, Sõmeru municipality, Aluvere village < Pilistvere Parish, 1912. J. Elken \& W. Rosenstrauch < Kai Sang, 83. Eesti regilaulude andmebaas. [Estonian Runic Songs Database.] Tartu: Estonian Folklore Archives, Estonian Literary Museum. Available at http://www.folklore.ee/regilaul/andmebaas, last accessed on 27 February 2018.

7 Translation source available at http://www.o-bible.com/cgibin/ob.cgi?version=bbe\&b ook=isa\&chapter=5, last accessed on 7 February 2018.

8 Translation source available at http://www.o-bible.com/cgibin/ob.cgi?version=bbe\&b ook=ecc\&chapter=11, last accessed on 7 February 2018.

9 Etymological databases on the web. Available at http://starling.rinet.ru/cgi-bin/main. cgi?root=config, last accessed on 27 February 2018.

\section{REFERENCES}

Aavik, Johannes 1921. Uute sõnade ja vähem tuntud sõnade sõnastik. Teine parandet ja suuresti täiendet trykk. [Glossary of New and Lesser Known Words. Second, Improved and Enlarged Edition.] Tallinn: A. Keisermann. 
Apresjan, Valentina 1997. Emotion Metaphors and Cross-Linguistic Conceptualization of Emotions. Cuadernos de Filologia Inglesa, Vol. 6, No. 2, pp. 179-195. Available at https://dialnet.unirioja.es/servlet/articulo?codigo=2526528, last accessed on 8 February 2018.

Buck, Carl Darling 1949. A Dictionary of Selected Synonyms in the Principal IndoEuropean Languages. Chicago: University of Chicago Press.

Dobrovol'skij, Dmitrij \& Piirainen, Elisabeth 2005. Figurative Language: Cross-Cultural and Cross-Linguistic Perspectives. Amsterdam: Elsevier.

EDE 2012 = Metsmägi, Iris \& Sedrik, Meeli \& Soosaar, Sven-Erik (comps. \& eds.) Eesti etümoloogiasõnaraamat. [The Etymological Dictionary of Estonian.] Tallinn: Eesti Keele Sihtasutus.

EED 2009 = Langemets, Margit \& Tiits, Mai \& Valdre, Tiia \& Veskis, Leidi \& Viks, Ülle \& Voll, Piret (eds.) Eesti keele seletav sõnaraamat. [The Explanatory Dictionary of Estonian.] Vol. I-VI. Tallinn: Eesti Keele Sihtasutus. Available at https://www. eki.ee/dict/ekss/ekss.html, last accessed on 8 February 2018.

Geeraerts, Dirk 2009. Deliteralization and the Birth of Emotion. A presentation held at a workshop of the FOCUS Foundation, Serock, Poland, 26 February. Slides available at http://wwwling.arts.kuleuven.be/qlvl/PDFPresentations/2009_Serock.pdf, last accessed on 8 February 2018.

Geeraerts, Dirk \& Grondelaers, Stefan 1995. Looking Back at Anger: Cultural Traditions and Metaphorical Patterns. In: J. Taylor \& R. MacLaury (eds.) Language and the Cognitive Construal of the World. Berlin \& New York: Mouton de Gruyter, pp. 153-179.

Gibbs, Raymond W., Jr. 2006. Embodiment and Cognitive Science. Cambridge: Cambridge University Press. https://doi.org/10.1017/CBO9780511805844.

Jannsen, Johann Voldemar 1854. Püssipappa essimessed Külla-Juttud külla rahwale: Essimenne öhtu. [Püssipappa's First Village Stories to Village People: The First Night.] Tartu: J. V. Jannsen.

Kama, Pikne 2017. How Old Is Runosong? Dating the Motifs of Burial-Related Folk Songs by Using Archaeological Material. Folklore: Electronic Journal of Folklore, Vol. 68, pp. 131-168. http://dx.doi.org/10.7592/FEJF2017.68.kama.

Khare, C. P. (ed.) 2004. Indian Herbal Remedies: Rational Western Therapy, Ayurvedic and Other Traditional Usage, Botany. Berlin \& Heidelberg \& New York: Springer.

Kövecses, Zoltán 2000. Metaphor and Emotion: Language, Culture and Body in Human Feeling. Cambridge: Cambridge University Press.

Kövecses, Zoltán 2005. Metaphor in Culture: Universality and Variation. Cambridge: Cambridge University Press.

Kövecses, Zoltán 2006. Embodiment, Experiential Focus, and Diachronic Change in Metaphor. In: R. W. McConchie \& O. Timofeeva \& H. Tissari \& T. Säily (eds.) Selected Proceedings of the 2005 Symposium on New Approaches in English Historical Lexis. Somerville, MA: Cascadilla Proceedings Project, pp. 1-7. Available at http://www.lingref.com/cpp/hel-lex/2005/, last accessed on 8 February 2018.

Kövecses, Zoltán 2008. Metaphor and Emotion. In: R. W. Gibbs, Jr. (ed.) The Cambridge Handbook of Metaphor and Thought. Cambridge: Cambridge University Press, pp. 380-395.

Kövecses, Zoltán 2015. Where Metaphors Come From? Reconsidering Context in Metaphor. Oxford: Oxford University Press. DOI:10.1093/acprof:oso/9780190224868.001.0001. 
Lakoff, George \& Johnson, Mark 1980. Metaphors We Live By. Chicago \& London: The University of Chicago Press.

Lakoff, George \& Johnson, Mark 1999. Philosophy in the Flesh: The Embodied Mind and Its Challenge to Western Thought. New York: Basic Books.

Langacker, Ronald W. 1987. Foundations of Cognitive Grammar I: Theoretical Prerequisites. Stanford, CA: Stanford University Press.

Lauluraamat 1727 [1721] = Eesti-Ma-Rahwa Laulo-Ramat, mis sees Önsa Lutterusse ja muud teised wannad ning ued kaunid Laulud on üllespandud. [Estonian Country Folk's Song Book.] Tallinn: Eestimaa Konsistooriumi kirjastuskassa. Available at http://www.digar.ee/arhiiv/et/raamatud/13552, last accessed on 27 February 2018.

Lee, Amy Pei-jung 2016. A Different Taste of Mind: Taste Terms and Emotion in Seediq. Paper presented at the First Cultural Linguistics International Conference, 20 22 July 2016, Prato, Tuscany, Italy.

Masing, Uku 2004. Keelest ja meelest. [On Language and Mind.] Tartu: Ilmamaa.

Osgood, Charles E. \& Suci, George J. \& Tannenbaum, Percy H. 1975 [1957]. The Measurement of Meaning. Urbana \& Chicago: University of Illinois Press.

Sharifian, Farzad 2011. Cultural Conceptualisations and Language: Theoretical Framework and Applications. Amsterdam \& Philadelphia: John Benjamins. http://doi. org/10.1075/clscc.1.

Soosaar, Sven-Erik 2016. Agape vastete kujunemisest eesti piiblitõlgetes. [On the Formation of the Equivalents of Greek agape in Estonian Bible Translations.] Emakeele Seltsi aastaraamat, Vol. 61, pp. 233-252. Tallinn: Teaduste Akadeemia Kirjastus.

Sutrop, Urmas 2002. The Vocabulary of Sense Perception in Estonian. Frankfurt am Main: Peter Lang.

Sweetser, Eve 1990. From Etymology to Pragmatics: Metaphorical and Cultural Aspects of Semantic Structure. Cambridge: Cambridge University Press. https://doi. org/10.1017/CBO9780511620904.

Vainik, Ene 2004. Lexical Knowledge of Emotions: The Structure, Variability and Semantics of the Estonian Emotion Vocabulary. Dissertationes Linguisticae Universitatis Tartuensis 5. Tartu: Tartu University Press. Available at http://dspace.ut.ee/ bitstream/handle/10062/756/Vainik.pdf?sequence=5\&isAllowed=y, last accessed on 8 February 2018.

Vainik, Ene 2014. Early Emotional Contacts with the Indo-Europeans: Lexical Evidence of Estonian against a Broader Background. Eesti ja soome-ugri keeleteaduse ajakiri / Journal of Estonian and Finno-Ugric Linguistics, Vol. 5, No. 2, pp. 139-167. http://dx.doi.org/10.12697/jeful.2014.5.2.07.

Vainik, Ene 2016. Eesti tunded: Sõnaportreed. [Estonian Feelings: Portraits of the Words.] Tallinn: Eesti Keele Sihtasutus.

Vainik, Ene 2017. Multiplicity of Motivation Behind Dynamic Descriptions of Emotion in Estonian. International Journal of Language and Culture, Vol. 4, No. 1, pp. 72-98. http://dx.doi.org/10.1075/ijolc.4.1.05vai.

Viberg, Åke 1983. The Verbs of Perception: A Typological Study. Linguistics, Vol. 21, No. 1, pp. 123-162. https://doi.org/10.1515/ling.1983.21.1.123.

Wilde, Peter Ernst 1771. Arsti ramat nende juhhatamisseks kes tahtwad többed ärraarwada ning parrandada. Eesti keelde ümbertöötanud August Wilhelm Hupel. [Medical Book for Those Who Want to Diagnose Illnesses and Treat Them. Translated into Estonian by August Wilhelm Hupel.] Põltsamaa: W. J. v. Lauw. Available at http://www2.kirmus.ee/grafo/index.php?ID=13, last accessed on 23 February 2018. 